\title{
Two poems by Chris Mann
}

\section{The Glimmer in the Moil}

It can't be what you think it is, spirituality. If it were, the soft white glimmering which blooms at night in the dim-lit waves heaving through the kelp below Cape Point, would comprehend the ocean's dark immensity.

It gathers, it seethes in the always just before, the just before you waken, blissfully at peace, before you hear yourself say on the phone, Sorry! or out of nowhere, turning on a tap in the shower, see Christ walking along a reed-edged shore.

Don't ask where it comes from, or why it's here. The moment it's thought about, even vaguely, it dies back into the moil and toil of the sea. Gone again, you say as you drowse at your desk. Gone for hours - till solitude unknows you, or prayer.

Cynics blacken, fanatics red-tide its bloom. If thought was plankton, and caritas oxygen, then prayer's the wave-pulse that gets it glowing. Without it, I'd never write a line, for all the kelp and sea-seethe in my psyche, the gloom.

\section{Abraham's Testimony}

The sky was grey, the sea leaden, The day I walked Armageddon. A fighter-jet roared through the sky, Down rural roads the tanks rolled by.

Canaan's a land as old as words, Old as thunder, the song of birds. Guidebook in hand, I climbed a mound, Looked out at G $\Omega$ d's ancestral ground.

Far-off - mountains, a smudge of rain, Hills with forests, a patch-worked plain, Green strips by brown, grain silos, dams, Orchards, bee-hives, milk cattle, lambs.

The jet flew low, my feelings gloomed. The landscape dimmed as history loomed, Compacted, showed a glint of spears From Egypt, Greece, in village squares,

Then Persian sword, Brit bayonet, Synagogue, church, and minaret, As if compressed in Canaan's bower, Clan, state and faith, grappled for power.
A past at one with drone-strike plumes, A schoolgirl raped in soldiers' rooms, Road-block, car-bomb, blackened stubble, Children playing on smoking rubble,

Beheaded men tossed from a truck, Blindfolded boys pushed off a ledge, Oil-fields in flames, whole towns in ruins As loathing raged in barred-up minds.

I shook my head, shut eyes and prayed, Sensed by a shrub, old Abram's shade. 'Come here!' he said. 'Now, take a look. Who's this inside your Holy Book?'

'You, sir', I said. 'Why the surprise? A scribe preserved, what three faiths prize, A One-G $\Omega d$ man, ram's horn in hand, Who fathered forth a promised land.'

'No, no!' he said, Not true enough, The scribe left out the human stuff. I cursed bad luck, and limped with gout, Lived with remorse, and months of doubt.

'I loved a drink, a joke, a laugh, Sarah, Hagar, my golden calf. I never meant Canaan to be A land of blood and bigotry.'

'Listen, earthling, don't feed on woes, Look at the stars - truth shrinks in prose. When men make $G \Omega d$ ink on a page The angels weep inside a cage'.

Abraham's voice has lingered long. Forgive me, friends, if I heard wrong. He took a twig, and cleared his throat, Bent to the dust, then speaking wrote:

'A prayer without uncertainty, A word without the mystery, A creed without the poetry Are dead to me as blasphemy'.

Tier after tier of ruined rock forts Lay underneath his swirl of thoughts. He faded then, without a sound, Back into time's reproachful mound.
Author: Chris Mann ${ }^{1}$

Affiliation: ${ }^{1}$ Institute for the Study of English in Africa, Rhodes University, South Africa

Corresponding author: Chris Mann, c.mann@ru.ac.za

How to cite this article: Mann, C., 2017, 'Two poems by Chris Mann', Literator 38(1), a1380. https://doi.org/10.4102/lit. v38i1.1380

Copyright: (C) 2017. The Authors. Licensee: AOSIS. This work is licensed under the Creative Commons Attribution License. 
A sparrow chirped beside my feet, A small wind stirred a field of wheat. The sun came out, a puddle gleamed; Canaan became a land I'd dreamed.

Author's note: 'Armageddon' is presently called Megiddo, a mound-like heritage site 30 miles south-east of Haifa. Located beside the Via Maris, the trade route joining Africa, Asia and
Europe, Armageddon has been the locus of epoch-changing wars for at least four millennia. These involved Egyptians, Canaanites, Judeans, Philistines, Assyrians, Persians, Greeks and Romans. 'Brit bayonets' refers to the Battle of Megiddo (1918) when Allied troops led by General Allenby defeated an army of the Ottoman Empire. At the time of writing, Israeli leaders were discussing 'a pre-emptive nuclear strike' against missile silos being constructed in Iran. 